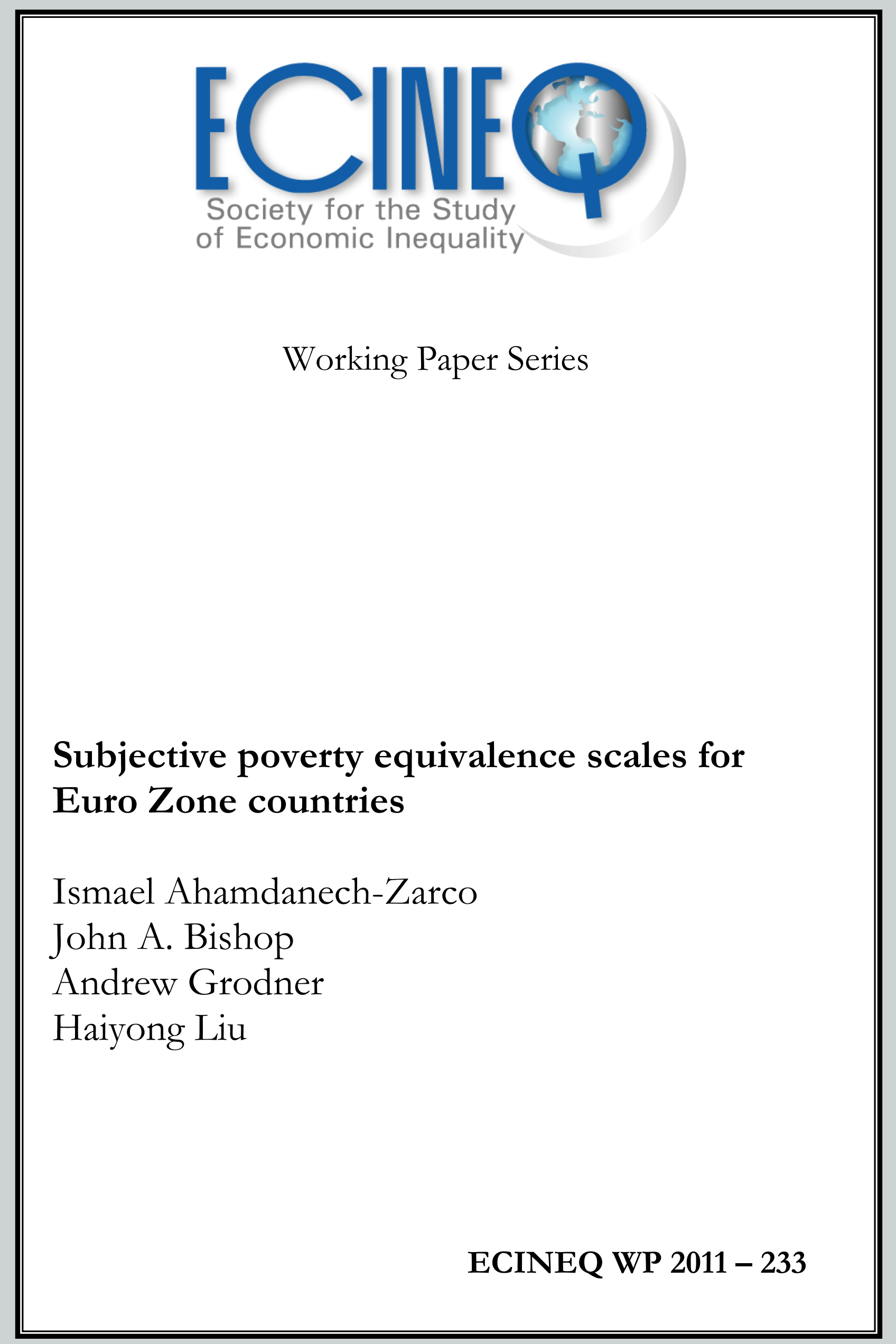




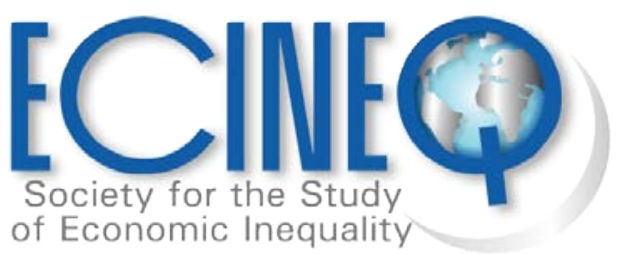

ECINEQ $2011-233$

November 2011

www.ecineq.org

\title{
Subjective poverty equivalence scales for Euro Zone countries
}

\author{
Ismael Ahamdanech-Zarco \\ John A. Bishop* \\ Andrew Grodner \\ Haiyong Liu \\ Department of Economics, East Carolina University
}

\begin{abstract}
While the idea behind subjective equivalence scales is generally attractive, subjective scales have been plagued by problems of inconsistency. We address this problem with new European Income and Living Conditions (SILC) datasets that are much larger in size than those available to previous researchers. We estimate subjective equivalence scales for the whole Euro Zone as well as its individual constituent countries. Our subjective scales increase consistently with household size. More importantly, we find that adding the first child is more costly than adding a third adult and that the marginal cost of children declines. Comparing modified OECD scale poverty rates to our subjective poverty rates (holding the overall poverty rate constant) we find that the subjective scales 'redistribute poverty' away from larger to smaller households.
\end{abstract}

Keywords: poverty, equivalence scales, subjective method, eurozone JEL classiffcation: I32, J13.

\footnotetext{
*Contact details: John Bishop, BishopJ@ecu.edu, Department of Economics, East Carolina University, Greenville, NC 28590. The authors would like to thank Bernard van Praag and the participants at the 4th ECINEQ meeting, Catania, Italy, July 2011.
} 


\section{Introduction}

Equivalence scales allow inter-household welfare comparisons by translating households of different compositions into equivalent individuals. This translation is necessary whenever we wish to make comparisons of economic wellbeing, devise means tests for income transfer, or identify the poor population. Furthermore, equivalence scales play a key role in devising taxes regimes and directly affect measured vertical and horizontal equity. A direct consequence of the equivalence scale estimation process is the inference of relative child costs. There are three well-known approaches to estimating equivalence scales: expert-based scales, demand system derived equivalence scales, and subjective equivalence scales. The focus of this paper is on subjective equivalence scales.

The idea behind subjective equivalence scales, simply asking people what the scale should be, seems to garner wide acceptance among applied welfare researchers. However, according to the National Research Council (1995) report on poverty measurements, "it is accepted that [subjective] equivalence scales are based more on their plausibility than on empirical evidence.” For example, the NRC reports that "the scales often do not consistently decrease with each additional household member” (p. 175). Explanations for the empirically poor performance include the difficulty of responding to questions that are very far away from topics of everyday experience.

An additional criticism of the subjective approach is that by design most empirical studies postulate underlying utility functions that are not consistent with actual consumer behavior (de Ree et al, 2010). The model specification typically employed rules out both price and base utility dependence. It can be shown that this leads to the empirically falsifiable prediction that observed patterns of consumptions are independent of income and household size. 
It is equally true that the competing alternatives to subjective equivalence scales, expertbased scales and demand system derived equivalence scales, suffer from their own set of shortcomings. Clearly, expert scales are somewhat arbitrary and easily open to debate about which goods are necessary and what their minimum levels should be. Alternatively, demand system based equivalence scales suffer from the well-known identification problem (Pollack and Wales, 1979). As described by the NRC, "these arguments suggest that in order to calculate the equivalence scale by comparing expenditure patterns, one needs to know the equivalence scale to begin with” (NRC, p. 169). In general, solving the identification problem requires adding arbitrary assumptions (Blackorby and Donaldson, 1993) or adding additional data (Olken, 2005).

In a recent paper Joppe de Ree, Rob Alessie and Menno Pradhan (2010) use responses to subjective welfare questions to address the identification problem. While addressing the demand system identification problem it also brings price and base utility dependence to the subjective analysis. Importantly, their primary conclusion is "these dependencies are not very large” (p. 37) and that "for practical purposes...equivalence scales that are just functions of demographics may suffice.” This finding of the sufficiency of demographic variables, together with the inclusion of subjective well-being questions in recently available large datasets, motivates a reconsideration of the usefulness of the subjective approach to measuring household equivalence scales.

Our approach to estimating subjective equivalence scales is based on responses to a “minimum needs" question. At this particular income level, Z*, individuals from different household structures who are at risk of poverty would have the same level of welfare. We would like to know the marginal rate of substitution between household size and household income at this welfare level $\left(Z^{*}\right)$, that is where the household income $\mathrm{Y}=\mathrm{Z}^{*}$, or where income is at the socially determined minimum. Our objective is to measure poverty and hence we do not need to 
know the entire welfare function, but only the shape of the social indifference curve at minimum needs income $\left(\mathrm{Z}^{*}\right)^{2}$

This paper estimates subjective equivalence scales for 15 Euro Zone countries. ${ }^{3}$ The data for our study comes from European Union Statistics (Eurostat) on Income and Living Conditions (SILC) database for the years 2004 to 2007; it is our conjecture that using this very large dataset (more than 300,000 households) can rectify the past problems of large variation and lack of consistency that has plagued the subjective approach. In fact, we find that "needs" increase consistently with household size. Comparing the modified OECD scale to our subjective scale we observe both greater economies of scale and a higher relative cost of children. Importantly, these findings hold for the Euro Zone as a whole as well as for the constituent countries.

We contrast our subjective scales to the modified OECD scales by constructing poverty profiles for each of the 15 Euro Zone countries. Holding the overall poverty rate constant at each countries' official “at risk” poverty rate, we find that a move from the OECD scales to our subjective scales lowers the relative poverty rate in three to four-adult households and raises poverty rates for one-adult households. Furthermore, the use of subjective scales results in higher relative poverty among one-child households and lower relative poverty for two-child households.

\section{Estimating Subjective Equivalence Scales}

Table 1 presents four commonly used equivalence scales as well as a subjective and demand-based equivalence scale for Italy. ${ }^{4}$ These equivalence scales differ both in the economies of scale of living in a household and in the marginal cost of the first and second child. The

\footnotetext{
${ }^{2}$ To extend the analysis to higher levels of income one would need to assume homothetic preferences.

${ }^{3}$ Estonia and Malta are excluded due to lack of data.

${ }^{4}$ De Vos and Zaidi (1997) provide subjective equivalence scales for Europe. Menon and Perali (2010) (see Table 5) provide equivalence scales for children from a number of expert, demand, and subjective equivalence scales studies. Also see van Praag, Hagenaars, and van Weeren et al. (1982).
} 
official US poverty scale postulates the greatest economies of scale while the National Research Council (NRC) scales show the smallest economies of scale. The marginal cost of the first child ranges from 0.26 (26 percent of a single adult equivalent) in the Orshansky (US) scale to 0.36 using the NRC scale. For the second child the OECD and NRC scales show little to no economies of scale among children while the Orshansky scale shows rising marginal cost of the second child (from 0.26 to 0.40 ). Only the square root rule shows economies of scale in adding an additional child as the marginal cost falls from 0.32 for the first child to 0.27 for the second child. The last two columns provide subjective and demand based equivalence scales for Italy. These two scales are surprisingly similar to each other and to the Orshansky scales.

The Intersection Method

Subjective poverty lines and equivalence scales can be based on answers to minimum income questions. ${ }^{5}$ The most common method for estimating subjective equivalence scales is the intersection method first developed by Goedhart et al. (1977). Garner and Short (2003) provide a detailed description of the intersection method.

We estimate the threshold $\left(Y^{*}\right)$ as the intersection of the relationship:

$$
\ln \left(Y_{\min }\right)=a_{0}+a_{1} \ln (Y)+a_{2} z_{2}+a_{3} Z_{3}+\ldots+a_{n} z_{n}+\varepsilon,
$$

with the line $Y_{\min }=Y$ for different values of $z_{n}\left(\mathrm{Y}_{\min }\right.$ is the answer to the minimum needs question, $\mathrm{Y}$ is income, and $z_{n}$ is a set of household structure indicator variables). The coefficient $a_{1}$ represents actual income elasticity of minimum needs income, $a_{0}$ represents log of needs income for one-adult household when actual income is zero, and coefficients $a_{2}, \ldots, a_{n}$ are differences in the log income for households with demographic structure $z_{j}$, relative to oneperson's household log income. Finally, $\epsilon$ is a classical error term.

\footnotetext{
${ }^{5}$ As Ravallion (2008) points out this approach is a special case of Van Praag's (1971) ordinal income evaluation question. The SILC data asks: "In your opinion, what is the very lowest net monthly income that your household would have to have in order to make ends meet?”
} 
The intersection approach is based on the assumption that only those individuals whose incomes are equal exactly to their minimum needs know their true minimum. In practice the only individuals who answer the subjective needs question correctly are those for whom $Y_{\min }=Y$. This implies that high actual income households tend to report higher minimum needs income and lower actual income households tend to report lower minimum needs income. However, as long as the reporting pattern is systematic and can be described by estimated equation (1), one does not need to have the data on individuals who are exactly at their minimum in order to calculate correct income thresholds.

Given that the intersection method is fundamentally driven by assuming systematically biased responses to the needs question, it is essential that the coefficients in (1) are precisely estimated. Thus, when using the data it is critical to clearly define different household types, $z_{j}$, which can be described by different household production functions. In addition, the cells with defined types of households should be large enough in size to allow for sufficient precision of estimates (the conditions which our data satisfies). If this is achieved then the approach can indeed identify the "true" minimum-spending thresholds by computing income at the intersections by using:

$$
Y^{*}\left(z_{2} \ldots z_{n}\right)=\exp \left[\frac{a_{0}+a_{2} z_{2}+\ldots+a_{n} z_{n}}{1-a_{1}}\right]
$$

When households have different family sizes, the responses would be expected to be different. For example, a four-adult household would be expected to report a higher minimum spending need than a three-adult household. The cost of an additional child is less apparent; for 
example, the first child may be accompanied a set of fixed child costs and there may be economies of scale in having children. ${ }^{6}$

\section{Data and Model Specification}

The data for our study comes from Eurostat's Statistics of Income and Living Conditions (SILC) database for the years 2004 to 2007. The SILC data includes the following question: "In your opinion, what is the very lowest net monthly income that your household would have to have in order to make ends meet?” We restrict our sample to the six most common family types, families with one to four adults (A1- A4), couples with a single child (A2K1), and two-child families (A2K2). ${ }^{7}$ Following OECD convention (as reflected in the modified OECD equivalence scales) we define adults as persons 15 years or older. One-adult (26.9 percent) and two-adult households (34.7 percent) make up more than half of our total sample (see Table 2, column 1). Couples with one child make up 7.4 percent of our sample, while couples with two children are 8.2 percent of the sample. Three and four-adult households comprise 13.8 and 8.2 percent of all households in our sample. Individual country-year (2007) data sets vary from 2742 households for Cyprus to 18,682 households for Italy. We pool the data for the years 2004 to 2007 and re-weight the data so that it is proportional to the population of the Euro zone countries. Our final pooled sample size is over 300,000 households.

To construct subjective equivalence scales we estimate a simple model with disposable income (Y) and family size indicator variables ${ }^{8}$,

$$
\ln \left(Y_{\text {min }}\right)=a_{0}+a_{1} \ln (Y)+a_{2} A 2+a_{3} A 3+. a_{4} A 4+a_{5} A 2 K 1+a_{6} A 2 K 2+e
$$

\footnotetext{
${ }^{6}$ For example, in our poverty calculations we use exogenously determined poverty cutoffs. Using the subjective method to estimate poverty thresholds can lead to high income regions (countries) having higher requirements and hence greater poverty than low income regions (c.f., Bishop, Luo, and Pan, 2006). However, differences in prices and perceptions are less relevant if our focus is on the relative cost across household sizes; i.e., the costs of a childless couple compared to a family with one child.

${ }^{7}$ These six household sizes make up approximately ninety percent of all euro zone households.

${ }^{8} \mathrm{We}$ also include country and year indicators.
} 
It is important to note that our goal is to obtain estimates of poverty thresholds for the major demographic groups. For example, we exclude single parent households in our data samples and estimates. We do this because such household types are rare in the Euro Zone countries, leading to small cell sizes. In addition, we restrict our model to these household size indicators (and income) alone in order not to contaminate our estimates. For example, including variables like marital status or heads’ age, which are clearly correlated with household structure, might explain some of the "inconsistent" results found in earlier studies.

\section{Estimation Results and Poverty Application}

The Euro Zone sample means, OLS regression coefficients, poverty thresholds, and subjective equivalence scales are presented in Table 2. For the Euro Zone as a whole we find a nominal mean annual income and monthly needs of 26,338 and 1,664 Euros. This implies subjective needs are, on average, about three-quarters of annual Euro Zone income. The adjusted $R^{2}$ is 0.5056 and the coefficients for all variables in our model are significant from zero at any conventional significance level. The regression results indicate that 1 percent increase in the annual total disposable income results in 0.304 percent increase in monthly minimum needs. Column 3 provides the monthly poverty thresholds as calculated using Equation (2). The oneadult poverty threshold is estimated at 356 Euros, while a family of three requires 583 Euros. The final column converts these thresholds in to equivalence scales.

\section{Subjective Equivalence Scales}

Examining the overall Euro Zone subjective equivalence scales (Table 2) results in several interesting findings. First, the subjective scales show consistently greater economies of scale within a household than the typical expert scale like the modified OECD scale or the NRC scale (see Table 1). For example, a three-adult household "costs" 100 percent more than a single individual under the OECD scale while only 52 percent more using the subjective scale. 
Comparing the Euro Zone scale to the official US scales we note that they are very similar for 2 and three-adult households.

Secondly, in addition to greater economies of scale the subjective scales also differ in the relative cost of children. The marginal cost of the first child in the subjective scale is 0.30 (1.641.34), the same as in the OECD scale. However, the subjective scales show a declining marginal cost of adding children $(0.14=1.78-1.64)$ as opposed to the OECD and NRC scales' constant marginal cost of children. Figure 1 compares the marginal costs of adults and children for three equivalence scales, the square root (SQR), the OECD, and the subjective scale (SUBJ).

Thirdly, we note that the cost of adding the first child (0.30) is greater than adding the third adult (0.18). All together our findings suggest that there are economies of scale in children's goods as well overall household size as economies of scale. Hence a family must first purchase a bundle of child specific goods, on which they can enjoy economies of scale. ${ }^{9}$

Table 3 provides subjective scales for each of the 15 Euro Zone countries as well as the overall Euro Zone scales. ${ }^{10}$ We first note that our overall Euro Zone scale is weighted and hence its similarity to Germany, France, and Italy, the largest Euro Zone countries. Returning to Table 1 our Italy scales are very similar to those of De Vos and Zaidi (1997). Overall, there are greater economies of scale in each of the 15 countries than that embodied in the expert-based OECD scale. The subjective equivalence scales increase with household size in all countries except the Netherlands. In all cases we find that the marginal cost of the first child exceeds the marginal cost of the third adult. We find the marginal cost of the second child is less than the marginal cost of the first child, again with the exception of the Netherlands. ${ }^{11}$ In general, we find that

\footnotetext{
${ }^{9}$ See Menon and Perali (2010) Table 5 for a list of demand studies indicating economies of scale among children.

${ }^{10}$ For a discussion of overall vs. country-specific equivalence scales, see DeVos and Zaidi $(1997 ; 1998)$ and Brandolini (2007).

${ }^{11}$ The Netherlands presents two problems for subjective scales estimation, a small sample size and a very low at risk poverty rate.
} 
countries with well-developed welfare states (a large degree of in-kind transfers) such as Netherlands, Germany, and Belgium show greater economies of scale than those countries with less well-developed welfare states (Spain, Portugal, and Greece). ${ }^{12}$

Application to Euro Zone Poverty Rates

Given the Euro Zone subjective poverty scale differs in important ways from the modified OECD scale, it is useful to examine how individual country poverty profiles might change if the Euro Zone subjective scale was adopted. Figure 2 plots the 95 percent confidence intervals for the "at risk" poverty rate using both the OECD and subjective scales. ${ }^{13}$ As expected the poverty rates are lower using the subjective scales; however, it is important to note that the change in equivalence scales does not alter the relative poverty rankings of the Euro Zone countries.

In addition to comparing overall poverty rates using alternative equivalence scales we also investigate changes in the "composition" of the poverty population. To facilitate the comparison between the OECD scales and the Euro Zone subjective scales we hold the overall "at risk" poverty constant at the official OECD rate. We then calculate the ratio of the subjective poverty rate to the OECD scale poverty rate for each of the six household sizes considered. Of course, this implies that the ratio for all household sizes combined is equal to one.

We present our findings in Table 4. Entries greater than one imply that the subjective poverty for that household size is greater than OECD poverty. Likewise, an entry less than one implies that OECD measured poverty is greater for that household size than subjective scale poverty.

\footnotetext{
${ }^{12}$ We thank Professor Bernard van Praag for pointing this out to us during his keynote speech at the 4th ECINEQ meeting, Catania, Italy, July, 2011.

13 The SILC data identifies the ‘at-risk’ population.
} 
Consider as an example, Austria (AT), where for one-adult households the ratio is 1.29. This implies that if 100 single-person households are poor using the OECD scales, then 129 single-person households will be deemed poor if we adopt the Euro Zone subjective scale. The 0.50 entry for three adults implies that for every 100 OECD poor in this demographic group, 50 households will be rated as poor by the subjective method. Finally, the 1.00 entry for two-adult households suggests that both scales result in an identical poverty rates. ${ }^{14}$

What types of patterns emerge when we compare poverty rates using these two equivalence scales? From the individual country results in Table 4 three generalizations emerge. First, we observe that the subjective scales "redistribute poverty" away from larger adult-only households (3-4 adult households) to one-adult households. Secondly, we observe higher poverty rates among one-child families. Thirdly, we observe that using subjective scales does not result in a higher poverty rate for two-child families. The last two findings can be explained by the fact that the marginal cost of adding the first child is greater than adding a third adult and that there are economies of scale in having children (a lower marginal cost of adding the second child).

\section{Conclusions}

While the idea behind subjective equivalence scales is generally attractive, subjective scales have been plagued problems of inconsistency. We argue that these problems can be addressed with estimation methods that focus on income and household composition variables alone, along with new data sets that are much larger in size than those available to previous researchers.

We estimate a Euro Zone wide and individual constituent countries subjective equivalence scales. Our Euro Zone scale consistently shows greater needs as household size increases. We find greater economies of scale than those embodied in the expert-based modified

\footnotetext{
${ }^{14}$ This unusual finding of no change in two-adult poverty rates with a change in equivalence scales implies that very few of these households can be found in the neighborhood of the poverty line.
} 
OECD scale. Importantly, we find that adding the first child is more costly than adding the third adult. This observation together with our finding of declining marginal cost of children implies that there are fixed costs of children, resulting in corresponding economies of scale of adding children. These fixed costs are not considered in the OECD scales and a major conclusion of our study is that policymakers need to be aware of these fixed costs when making child support funding decisions.

We compare poverty profiles for Euro Zone countries based on the modified OECD and the subjective scales. Moving from the OECD scale to the subjective scale lowers the overall poverty rate but it does not alter the relative poverty rankings of the Euro Zone countries. When we hold the poverty rate constant at the official level the subjective scales "redistribute poverty" away from larger adult-only households (households with 3-4 adults) to one-adult households. Additionally, using the subjective scale in place of the OECD scale results in a higher poverty rate for one-child families and a slightly lower poverty rate for two-child families. In sum, the adoption of the subjective equivalence scales would leave the poverty rankings among countries unchanged, but would direct more resources to single-adult and one-child families than under the currently used modified OECD scales. 


\section{References}

Bishop, J., Luo, F, and X. Pan (2006). "Economic transition and subjective poverty in urban China,” Review of Income and Wealth, 52, 525-642.

Blackorby, C. and Donalson, D. (1993). "Adult-equivalence scales and the economic implementation of interpersonal comparisons of well-being," Social Choice and Welfare, 10, 335-361.

Brandolini, A. (2007). "Measurement of income distribution and poverty in supranational entities: The case of the European Union,” in S. Jenkins and J. Micklewright (eds.), Inequality and Poverty Re-examined, Oxford, Oxford University Press, pp 62-83.

De Vos, K, and Zaidi, A. M. (1997). "Equivalence scale sensitivity of poverty statistics for member states of the European Community,” Review of Income and Wealth, 43 (3), 319-333.

De Vos, K, and Zaidi, A. M. (1998). "Poverty measurement in the European Union: Countryspecific or union-wide poverty lines?” Journal of Income Distribution, 8 (1), 77-92.

De Ree, J., Alessia, R., and Pradhan, M. (2010). "The price and utility dependence of equivalence scales: Evidence from Indonesia, unpublished manuscript.

Garner, T. and Short, K. (2003). "Personal assessments of minimum income and expenses: What do they tell us about 'minimum living'thresholds and equivalence scales," in Y. Amiel and J. A. Bishop (eds.), Inequality, Welfare, and Poverty; Theory and Measurement, Research on Economic Inequality, Vol. 10, 191-244, London: JAI Press.

Goedhart; T., Halberstadt, V., Kapteyn, A. and B. van Praag (1977). “The poverty line: Concept and measurement,” The Journal of Human Resources, Volume 12, Issue 4 (Autumn), 503-520

Menon, M, and Perali, F. (2010). "Econometric identification of the cost of maintaining a child," in J. Bishop (ed.), Studies in Applied Welfare Analysis: Papers from the Third ECINEQ Meeting, Emerald, London, pp. 219-255.

Olken, B. A. (2005). “Revealed community equivalence scales,” Journal of Public Economics, 89, 545-566.

Ravallion, M. (2008) “Poverty lines," in The New Palgrave Dictionary of Economics, $2^{\text {nd }}$ edition, L. Blume and S. Durlaf (eds.), London: Plagrave Macmillian.

Eurostat (2009) Description of SILC user database variables, Version 2007.1, Luxembourg.

van Praag, B. (1971). "The welfare function of income in Belgium: An empirical investigation," European Economic Review, Elsevier, vol. 2(3), pages 337-369.

van Praag, B., Hagenaars, A.and van Weeren, H. (1982). "Poverty in Europe," Review of Income and Wealth, Blackwell Publishing, vol. 28, 345-59. 
Table 1

Alternative Equivalence Scales

\begin{tabular}{|c|c|c|c|c|c|c|}
\hline $\begin{array}{c}\text { Household } \\
\text { Composition }\end{array}$ & $\begin{array}{c}\text { Modified } \\
\text { OECD }\end{array}$ & $\begin{array}{c}\text { Orshanky } \\
\text { (US) }\end{array}$ & $\begin{array}{c}\text { Square } \\
\text { Root } \\
\text { Rule }\end{array}$ & $\begin{array}{c}\text { National } \\
\text { Research } \\
\text { Council }^{1}\end{array}$ & $\begin{array}{c}\text { De Vos } \\
\text { Zaidi } \\
\text { (Italy) }^{2}\end{array}$ & $\begin{array}{c}\text { Menon } \\
\text { Perali } \\
\text { Italy) }^{3}\end{array}$ \\
\hline 1 Adult & 1.00 & 1.00 & 1.00 & 1.00 & 1.00 & 1.00 \\
\hline 2 Adults & 1.50 & 1.29 & 1.41 & 1.62 & 1.29 & 1.25 \\
\hline 3 Adults & 2.00 & 1.50 & 1.73 & 2.18 & -- & 1.34 \\
\hline 4 Adults & 2.50 & 1.98 & 2.00 & 2.64 & -- & -- \\
\hline 2 Adults 1 Child & 1.80 & 1.55 & 1.73 & 2.00 & 1.50 & 1.48 \\
\hline 2 Adults 2 Children & 2.10 & 1.95 & 2.00 & 2.35 & 1.67 & 1.71 \\
\hline
\end{tabular}

Notes: 1. Expert scale from National Research Council (1995); 2. Subjective scale from De Vos and Zaidi (1997), Appendix Table 1; 3. Demand System (QAIDS) scale from Menon and Perali (2010), Table 4. 
Table 2

Subjective Poverty Thresholds and Equivalence Scales,

All Euro Zone Countries, 2004-2007

\begin{tabular}{|c|c|c|c|c|}
\hline & $\begin{array}{c}\text { Sample Mean } \\
\text { (1) }\end{array}$ & $\begin{array}{c}\text { Regression } \\
\text { Coefficient }^{2} \\
(2)\end{array}$ & $\begin{array}{c}\text { Poverty } \\
\text { Threshold } \\
(3)\end{array}$ & $\begin{array}{c}\text { Equivalence } \\
\text { Scale } \\
(4)\end{array}$ \\
\hline 1 Adult & 0.269 & -- & 356 & 1.00 \\
\hline 2 Adults & 0.347 & $\begin{array}{l}0.2040 \\
(.0020)\end{array}$ & 477 & 1.34 \\
\hline 3 Adults & 0.138 & $\begin{array}{l}0.2898 \\
(.0028)\end{array}$ & 540 & 1.52 \\
\hline 4 Adults & 0.088 & $\begin{array}{l}0.3827 \\
(.0034)\end{array}$ & 617 & 1.73 \\
\hline 1 Child & 0.074 & $\begin{array}{l}0.3436 \\
(.0032)\end{array}$ & 583 & 1.64 \\
\hline 2 Children & 0.082 & $\begin{array}{l}0.3996 \\
(.0034)\end{array}$ & 632 & 1.78 \\
\hline $\begin{array}{l}\text { Annual } \\
\text { Income }\end{array}$ & 26,338 & $\begin{array}{l}0.3042 \\
(.0013)\end{array}$ & -- & -- \\
\hline $\begin{array}{l}\text { Lowest } \\
\text { Monthly } \\
\text { Income } \\
\end{array}$ & $\begin{array}{c}1,664 \\
--\end{array}$ & $\begin{array}{l}-- \\
--\end{array}$ & $\begin{array}{l}-- \\
--\end{array}$ & -- \\
\hline Constant & -- & 4.089 & -- & -- \\
\hline \# of obs. & \multicolumn{4}{|c|}{306,454} \\
\hline
\end{tabular}

Notes: 1. Sample includes 15 Euro Zone countries, weighted by population size; 2. Regression includes country indicators (Luxembourg omitted) and year indicators (2006 omitted); 3. Both lowest monthly income (dependent variable) and annual income are log transformations in the regression. 
Table 3

Subjective Equivalence Scales for Euro Zone Countries

\begin{tabular}{|c|c|c|c|c|c|c|}
\hline \multirow{2}{*}{ Country } & \multicolumn{7}{|c|}{ Family Size } \\
\cline { 2 - 7 } & $\begin{array}{c}\text { Single } \\
\text { Adult }\end{array}$ & $\begin{array}{c}\text { Two } \\
\text { Adults }\end{array}$ & $\begin{array}{c}\text { Three } \\
\text { Adults }\end{array}$ & $\begin{array}{c}\text { Four } \\
\text { Adults }\end{array}$ & $\begin{array}{c}\text { One } \\
\text { Child }\end{array}$ & $\begin{array}{c}\text { Two } \\
\text { Children }\end{array}$ \\
\hline Euro Zone & 1.00 & 1.34 & 1.52 & 1.73 & 1.64 & 1.78 \\
\hline AT & 1.00 & 1.35 & 1.53 & 1.74 & 1.65 & 1.71 \\
\hline BE & 1.00 & 1.21 & 1.31 & 1.57 & 1.50 & 1.61 \\
\hline CY & 1.00 & 1.29 & 1.68 & 2.40 & 2.29 & 2.60 \\
\hline DE & 1.00 & 1.37 & 1.52 & 1.68 & 1.54 & 1.72 \\
\hline ES & 1.00 & 1.33 & 1.50 & 1.71 & 1.83 & 1.99 \\
\hline FI & 1.00 & 1.20 & 1.43 & 1.71 & 1.78 & 2.04 \\
\hline FR & 1.00 & 1.36 & 1.55 & 1.79 & 1.59 & 1.66 \\
\hline GR & 1.00 & 1.32 & 1.77 & 2.14 & 1.89 & 2.09 \\
\hline IE & 1.00 & 1.39 & 1.50 & 1.68 & 1.99 & 2.20 \\
\hline IT & 1.00 & 1.28 & 1.49 & 1.75 & 1.58 & 1.69 \\
\hline LU & 1.00 & 1.22 & 1.26 & 1.55 & 1.56 & 1.71 \\
\hline NL & 1.00 & 1.31 & 1.30 & 1.38 & 1.46 & 1.62 \\
\hline PT & 1.00 & 1.51 & 1.80 & 1.97 & 1.95 & 2.20 \\
\hline SI & 1.00 & 1.41 & 1.69 & 1.97 & 1.82 & 2.00 \\
\hline SK & 1.00 & 1.18 & 1.55 & 1.86 & 1.55 & 1.63 \\
\hline
\end{tabular}

Note: Calculations based on estimating equation (1). 
Table 4

Ratio of Poverty Rates Based on Subjective Scale vs. OECD Scale (Year 2007)

\begin{tabular}{|c|c|c|c|c|c|c|c|}
\hline \multirow{2}{*}{ Country } & \multicolumn{7}{|c|}{ Family Size } \\
\cline { 2 - 8 } & All & $\begin{array}{c}\text { One } \\
\text { Adult }\end{array}$ & $\begin{array}{c}\text { Two } \\
\text { Adults }\end{array}$ & $\begin{array}{c}\text { Three } \\
\text { Adults }\end{array}$ & $\begin{array}{c}\text { Four } \\
\text { Adults }\end{array}$ & $\begin{array}{c}\text { One } \\
\text { Child }\end{array}$ & $\begin{array}{c}\text { Two } \\
\text { Children }\end{array}$ \\
\hline AT & 1.00 & 1.29 & 1.00 & 0.50 & 0.34 & 1.04 & 0.78 \\
\hline BE & 1.00 & 1.36 & 0.98 & 0.58 & 0.49 & 1.08 & 0.88 \\
\hline CY & 1.00 & 1.16 & 1.06 & 0.66 & 0.63 & 1.13 & 1.00 \\
\hline DE & 1.00 & 1.22 & 0.99 & 0.69 & 0.54 & 1.04 & 0.90 \\
\hline ES & 1.00 & 1.23 & 1.14 & 0.77 & 0.66 & 1.21 & 0.93 \\
\hline FI & 1.00 & 1.30 & 1.00 & 0.52 & 0.37 & 1.16 & 0.79 \\
\hline FR & 1.00 & 1.44 & 1.05 & 0.52 & 0.46 & 1.20 & 0.86 \\
\hline GR & 1.00 & 1.27 & 1.13 & 0.77 & 0.59 & 1.14 & 1.02 \\
\hline IE & 1.00 & 1.17 & 0.95 & 0.60 & 0.51 & 1.03 & 0.86 \\
\hline IT & 1.00 & 1.26 & 1.13 & 0.72 & 0.55 & 1.20 & 0.97 \\
\hline LU & 1.00 & 1.29 & 1.09 & 0.69 & 0.41 & 1.17 & 0.98 \\
\hline NL & 1.00 & 1.54 & 0.88 & 0.35 & 0.33 & 0.97 & 0.72 \\
\hline PT & 1.00 & 1.39 & 1.04 & 0.71 & 0.56 & 1.07 & 1.00 \\
\hline SI & 1.00 & 1.44 & 1.30 & 0.67 & 0.40 & 1.26 & 1.00 \\
\hline SK & 1.00 & 1.98 & 1.06 & 0.58 & 0.52 & 1.32 & 0.90 \\
\hline
\end{tabular}

Note: This table holds overall poverty constant at modified OECD rates. 
Figure 1

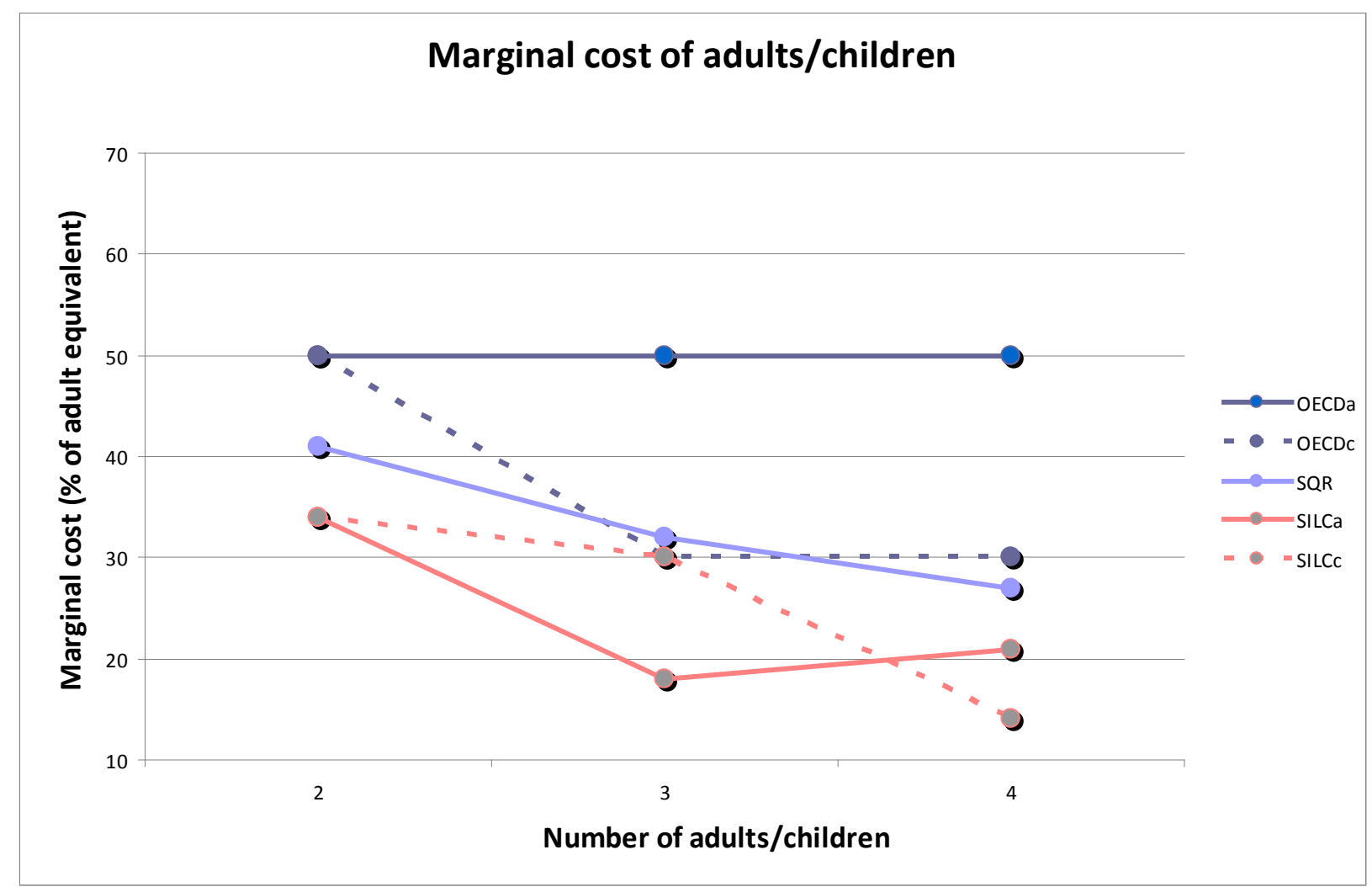

Note: SQR is the square root rule, SILC denotes subjective scale, subscripts $a$ denotes adults, and $c$ denotes children. 
Figure 2: 95 Percent Confidence Interval for Poverty Rates with OECD Scale and Subjective Scale

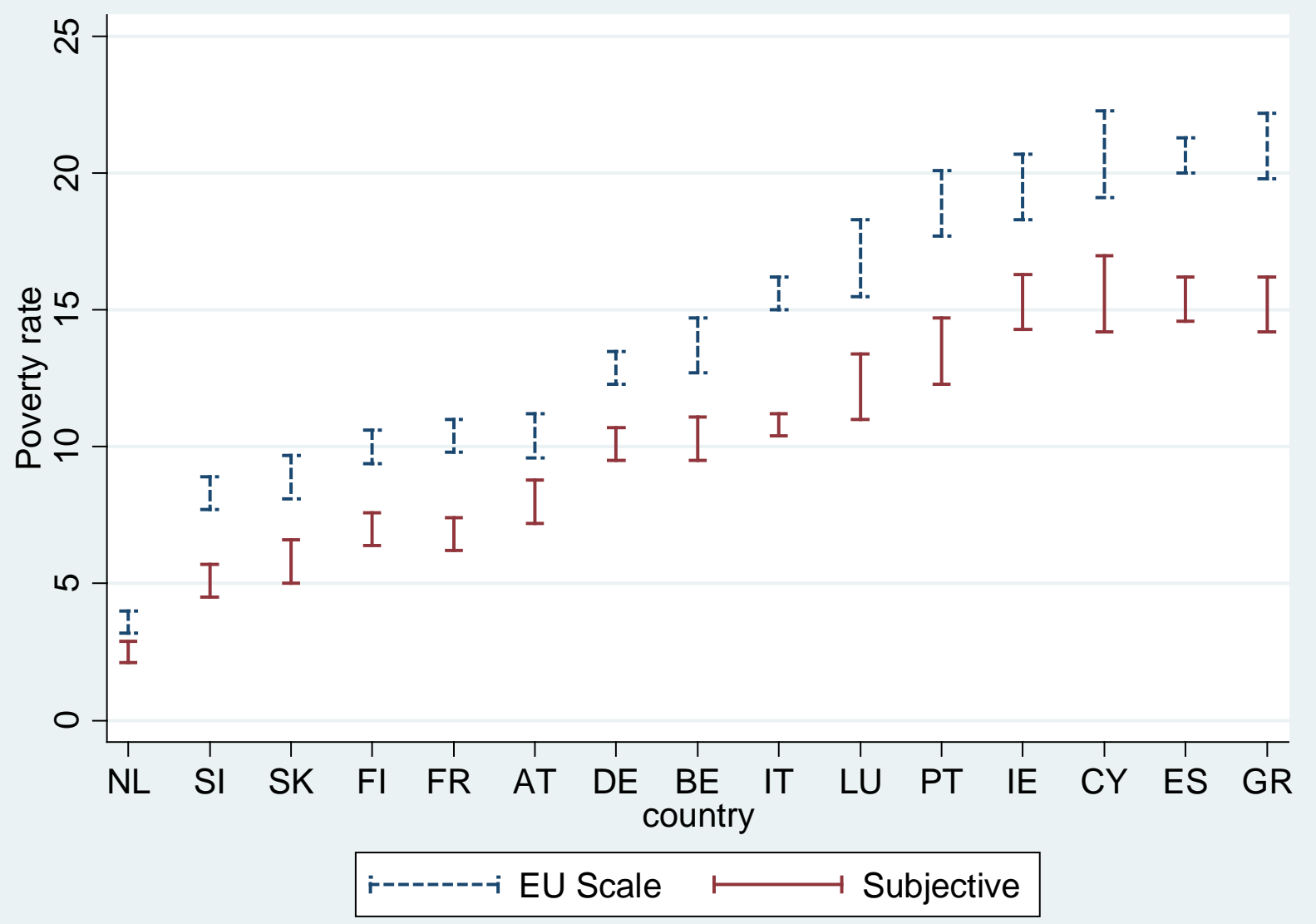

